\title{
Monitoring of Paraquat in soya products intended for animal feed
}

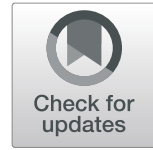

\author{
Franziska Heydebreck
}

\begin{abstract}
Even though paraquat is considered to be one of the most toxic herbicides, it is one of the most used ones. Paraquat-based preparations are heavily used across many important agricultural countries and for a lot of types of crops such as soya. As soya is used in large quantities in the feed production, paraquat residues in soya products are a potential threat to livestock. The aim of this study was to investigate whether soya products intended for animal feed contain residues of paraquat. Therefore, an optimized Quick Polar Pesticides (QuPPe) Method was developed. In total, 174 samples were analyzed via LC-MS/MS using zwitterionic hydrophilic interaction liquid chromatography (ZIC-HILIC). The results showed that paraquat was detected in $66 \%$ of the samples above $0.008 \mathrm{mg} / \mathrm{kg}$. Residues were mainly present in soya bean meals that were imported from Brazil or the USA and cultivated using genetically modified soya. Around $5 \%$ of the samples were not compliant with the European regulation on maximum residue levels of pesticides in or on food and feed. The results of this study support the view that paraquat residues play a significant role in soya products intended for animal feed and, thus, need to be controlled on a regular basis. However, for enforcement actions reliable processing factors for paraquat in soya products or maximum residue levels for processed soya products are urgently required.
\end{abstract}

Keywords: Paraquat, Pesticides, Herbicides, Soya, Animal feed, European Union, Brazil, GMO, QuPPe

\section{Introduction}

Paraquat is widely considered to be one of the most toxic herbicides currently used. It has been shown that the presence of paraquat can cause harmful effects on terrestrial and aquatic ecosystems (Babatunde et al., 2001; Leboulanger et al., 2009; Muangphra et al., 2014) and human health (Wesseling et al., 2001; Tanner et al., 2011). For example, as paraquat tends to accumulate mainly in the lung, various pulmonary effects, such as wheeze and shortness of breath, have been associated with paraquat exposure of farmers (Hoppin et al., 2002; Schenker et al., 2004). Furthermore, it has been reported that chronic paraquat exposure might contribute to the development of Parkinson's disease in humans (DinisOliveira et al., 2006; Costello et al., 2009; Tanner et al.,

\footnotetext{
Correspondence: Franziska.Heydebreck@laves.niedersachsen.de

Feed Institute, Lower Saxony State Office for Consumer Protection and Food Safety, Heckenweg 6, 21680 Stade, Germany
}

2011). Nevertheless, it is still one of the best-selling herbicides worldwide used for a huge variety of crops, including maize, rice and soya beans (Syngenta Crop Protection AG, 2019).

Paraquat is known for its very effective and fast-acting behavior in killing weeds. It may also be used as a desiccant to hasten maturity of a crop to prepone the harvest date (Boudreaux and Griffin, 2011). However, when paraquat is applied shortly before harvest, residues may be leaved on plant and crop and, thus, may pose a threat to consumers. In the European Union (EU), the authorization of paraquat-based preparations is suspended since 2007. Thus, it is currently not allowed to sell and apply paraquat in the member states of the EU (EuG, 2007). However, paraquat is still authorized and extensively used across many important agricultural countries, including the USA and Brazil (Syngenta Crop Protection AG, 2019).

C C The Author(s). 2021 Open Access This article is licensed under a Creative Commons Attribution 4.0 International License, which permits use, sharing, adaptation, distribution and reproduction in any medium or format, as long as you give appropriate credit to the original author(s) and the source, provide a link to the Creative Commons licence, and indicate if changes were made. The images or other third party material in this article are included in the article's Creative Commons licence, unless indicated otherwise in a credit line to the material. If material is not included in the article's Creative Commons licence and your intended use is not permitted by statutory regulation or exceeds the permitted use, you will need to obtain permission directly from the copyright holder. To view a copy of this licence, visit http://creativecommons.org/licenses/by/4.0/ The Creative Commons Public Domain Dedication waiver (http://creativecommons.org/publicdomain/zero/1.0/) applies to the data made available in this article, unless otherwise stated in a credit line to the data. 
Chemically seen, paraquat (1,1'-dimethyl-4,4'-bipyridinium) is a cation associated twice with chloride as anion. It belongs to the group of bipyridyl herbicides and quaternary ammonium salts. Paraquat is a very polar substance with a high solubility in water of $620 \mathrm{~g} / \mathrm{L}$ (National Center for Biotechnology Information, 2020). Because of its ionic nature and high polarity, the analysis of paraquat has been reported in the literature as difficult and challenging. Numerous analytical methods and techniques have been suggested, including gas chromatography (Kawase et al., 1984), capillary electrophoresis (Mallat et al., 2001), immunoassay (Garcia-Febrero et al., 2014), voltammetry (Souza et al., 2006), and spectrophotometry (Shivhare and Gupta, 1991). Liquid chromatography coupled with mass spectrometry via electrospray ionization has become the most common approach, although several problems with the chromatographic (e.g. limited retention and poor peak shape) and mass spectrometric (e.g. various types of quasi-molecular ions and multiple reaction monitoring transitions) behavior of paraquat are described.

The soya bean is the most important oil plant worldwide, with a global oil plant cultivation area of $46 \%$ in 2017 (Ovid, 2018). Soya is a key factor in animal feeding due to its high protein content and profitable cultivation. Soya beans and soya products intended for animal feed are mainly imported from non-EU countries into the EU. In 2017, for example, 14.4 million tons and 20.8 million tons soya beans and soya bean meal, respectively, were imported to the EU (Ovid, 2018). The majority of soya beans was imported from the USA and Brazil (>70\%), whereas about $87 \%$ of the soya bean meal originated from Brazil and Argentina (Ovid, 2018). In those countries, almost $100 \%$ of the cultivation area is cultivated with genetically modified soya like glyphosate-resistant varieties (Ovid, 2018). However, the intensive use of glyphosate has led to the development of many glyphosate-resistant weeds over the past years (Powles, 2008; Perry et al., 2016; Syngenta Crop Protection AG, 2019). Because paraquat is an important alternative non-selective herbicide, it is very likely that paraquat-based formulations are used as harvest aids to soya beans in those countries. Consequently, imported crops can contain residues of paraquat that might be above permitted tolerances and also be a significant route to a prolonged exposure of both animals and humans to paraquat.

The purpose of this study was to investigate whether soya products intended for animal feed contain residues of paraquat. Furthermore, differences in concentration levels between the various soya products and regions of origin as well as genetically modified soya and non- genetically modified soya should be evaluated and discussed.

\section{Materials and methods \\ Samples}

Samples were chosen and collected by official feed control inspectors. All sampling sites were located in the German state Lower Saxony and covered a broad spectrum of facilities, including various manufacturers of compound feeding stuffs and the port of Brake on the Weser River, which is an important import cargo spot for feed stock in Europe. The aim was to take samples evenly balanced between various soya products, regions of origin and import countries, and between genetically modified and non-genetically modified material. A particular focus was set on soya bean meal because it is used most for the production of compound feeding stuffs. In total, 174 soya products were collected during the years 2018 and 2019 (Table 1).

Table 1 Overview of the sample material

No. of samples

Soya product

Soya bean meal (partly steam-heated or dehulled) 144

Soya beans (untreated, steam-heated or toasted) 11

Soya bean protein concentrate $\quad 10$

Soya bean expeller 7

Soya bean hulls $\quad 2$

Genetically modified soybeans

Genetically modified organism (GMO) 94

Non-GMO

68

Unknown

12

Region of origin

Brazil 88

Argentina 11

Russia $\quad 11$

India 6

USA 4

Ukraine 2

PR China 2

Austria 2

Canada 1

Lithuania 1

North America 1

Norway 1

Unknown ${ }^{\text {b }} 44$

${ }^{a}$ Detailed definitions of the various soya products are given in the official catalogue of feed materials (European Commission, 2017a)

${ }^{b}$ Especially for samples from manufacturers of compound feeding stuffs, the region of origin and the point of entry into the EU had to be marked as "Unknown" because there is no obligation to label where feed materials were cultivated 


\section{Chemicals}

Acetonitrile and methanol (both HPLC gradient grade; $\geq$ 99.9\%) were purchased from Honeywell (Seelze, Germany). Formic acid (ACS/Reag. Ph. Eur.; 98-100\%), ammonium formate (for LC-MS; $\geq 99.0 \%$ ), and hydrochloric acid fuming $37 \%$ (for analysis) were purchased from Merck (Darmstadt, Germany). Ultra-pure water of type 1 grade (American Society for Testing and Materials, ASTM) was supplied by a Sartorius arium system (Göttingen, Germany). Reference standards of paraquat dichloride (CAS-No. 1910-42-5; purity $97.5 \% \pm 1.0 \%$ ) and paraquat diiodide-d6 (purity $96.5 \%$ ) were purchased from LGC Standards (Wesel, Germany). Standard stock solutions of paraquat dichloride and paraquat diiodided6 were prepared at approx. $1 \mathrm{mg} / \mathrm{mL}$ in methanol and were stored in a freezer at $-20{ }^{\circ} \mathrm{C}$. Before use, they were placed in an ultrasonic bath for $10 \mathrm{~min}$ to obtain complete dissolution and they were allowed to reach room temperature afterwards. From the standard stock solutions, working standard solutions with concentrations of approx. $10 \mu \mathrm{g} / \mathrm{mL}$, respectively, were prepared and handled according to the standard stock solutions. The working standard solutions were used to prepare fresh daily spiking and calibration solutions with concentrations of approx. $0.4 \mu \mathrm{g} / \mathrm{mL}$ and $0.08 \mu \mathrm{g} / \mathrm{mL}$ in methanol.

\section{Sample preparation}

Samples were extracted following the Quick Polar Pesticides (QuPPe) Method developed by the EU Reference Laboratory for Single Residue Methods (Anastassiades et al., 2016). However, modifications were made to the QuPPe-Method and are discussed in detail in the Results and Discussion section.

Samples were quartered and milled to a final particle size of $0.5 \mathrm{~mm}$ using an ultra-centrifugal mill. $5 \mathrm{~g} \pm$ $0.05 \mathrm{~g}$ were weighed into a $50 \mathrm{~mL}$ polypropylene tube, spiked with $25 \mu \mathrm{L}$ of the paraquat diiodide-d6 working standard solution $(10 \mu \mathrm{g} / \mathrm{mL})$ and blended. $25 \mathrm{~mL}$ of the extraction solvent (methanol/0.5 M hydrochloric acid, $60 / 40, \mathrm{v} / \mathrm{v}$ ) were added, blended using a Vortex mixer, and extracted for $15 \mathrm{~min}$ using a horizontal shaker. The extract was then centrifuged at $4369 \mathrm{x} \mathrm{g}$ and $10{ }^{\circ} \mathrm{C}$ for $15 \mathrm{~min}$. Approx. $1 \mathrm{~mL}$ of the supernatant was filtrated through a $0.2 \mu \mathrm{m}$ regenerated cellulose membrane syringe filter (CHROMAFIL ${ }^{\circ}$ Xtra RC-20/13, MachereyNagel) and diluted 1:2 with a mixture of methanol and ultra-pure water $(60 / 40, \mathrm{v} / \mathrm{v}) .5 \mu \mathrm{L}$ of this solution was injected into the LC-MS/MS system.

\section{Instrumental analysis}

Samples were analyzed according to the QuPPe-Method (Anastassiades et al., 2016), but likewise with modifications (cf. section Results and Discussion). All samples were analyzed through an LC-MS/MS system using a 1260 Infinity system coupled to a 6470-mass spectrometer (both Agilent Technologies). Analysis was performed using positive electrospray ionization, with unit resolution in Q1 and Q3, and in multiple reaction monitoring (MRM) mode. MRM transitions were 186> $174 \mathrm{~m} / \mathrm{z}$ (quantification) and $186>77 \mathrm{~m} / \mathrm{z}$ (confirmation) for paraquat and $192>174 \mathrm{~m} / \mathrm{z}$ for paraquat-d6. High performance liquid chromatography was performed using a SeQuant ZIC ${ }^{\oplus}$-HILIC column $(2.1 \times 150$ mm, $5 \mu \mathrm{m}, 200 \AA$; Merck) combined with an Opti-Lynx Guard column $(2.1 \times 15 \mathrm{~mm}$; Optimize Technologies $)$. The mobile phase consisted of (A) ultra-pure water, added with ammonium formate $(0.02 \mathrm{~mol} / \mathrm{L})$ and adjusted to $\mathrm{pH} 3$ with formic acid, and (B) acetonitrile. The gradient profile was achieved at a flow rate of 200 $\mu \mathrm{L} / \mathrm{min}$ and initiated with an equilibration phase of $20 \%$ A for 7 min, which was increased to $80 \%$ A within $4 \mathrm{~min}$ and hold for $10 \mathrm{~min}$. The column was heated constantly at $40{ }^{\circ} \mathrm{C}$.

\section{Quality assurance and quality control}

Calibration solutions were injected at the start and end of every sample sequence and bracketing calibration was used for quantification. All calibration graphs were linear and non-weighed. The calibration levels usually ranged from $0 \mathrm{ng} / \mathrm{mL}$ to approx. $12 \mathrm{ng} / \mathrm{mL}$ ( $\hat{=}$ $0,060 \mathrm{mg} / \mathrm{kg}$ ) (4-point calibration). When higher concentrations were quantified, samples were re-analyzed including one higher calibration point. Concentrations were quantified using solvent based calibration curves obtaining the relative response of the target analyte to the amount of the mass-labeled internal standard. Sample concentrations were calculated on a basis of the paraquat dication, so a conversion factor of 0.598 was used to take into consideration that the reference standard was sold as a salt and with remaining water content. The analytical method was fully validated according to the Analytical quality control and method validation procedures for pesticide residues analysis in food and feed (European Commission, 2015; European Commission, 2017b). During the method validation, blank samples were spiked with paraquat at concentrations of $38 \mu \mathrm{g} / \mathrm{kg}, 15.2 \mu \mathrm{g} / \mathrm{kg}$, and $7.6 \mu \mathrm{g} / \mathrm{kg}(\mathrm{n}=5-10)$. For these spiked levels, precision values of $6.5 \%, 4.1 \%$, and $5.1 \%$ and trueness values of $100 \%$, 94\%, and $89 \%$ were yielded, respectively. The limit of quantification (LOQ) was defined as the lowest spiked level that meets the method performance acceptability criteria (i.e. precision $\leq 20 \%$ and trueness between 70 and $120 \%$ ). Accordingly, the LOQ was set to $0.008 \mathrm{mg} / \mathrm{kg}$. As paraquat tends to interact with glass-surfaces, polypropylene tubes and vials were used at all stages of the sample preparation and analysis. Instrumental blanks 
could be reduced by using capillaries made of stainless steel instead of polyether ether ketone (PEEK). During a sample sequence, numerous blank injections were made to minimize the carryover of calibration injections. One procedural blank sample was extracted with every sample batch. In general, procedural blank contaminations were low $(\varnothing 0.001 \mathrm{mg} / \mathrm{kg}$ ) and originated most probably from instrumental contamination. They were not taken into consideration when calculating sample concentrations. The modified method has been successfully tested $(\mathrm{z}$-score $=0.0)$ in a ring trial between eight laboratories. The ring trial material was used afterwards as reference material in every sample batch to check trueness and precision (precision $=12 \%$; trueness $=87 \% ; \mathrm{n}=33$ ). In addition, various spiked matrices (sunflower seed meal, rape seed meal, barley) were analyzed in every sample batch (precision $=15 \%$; trueness $=89 \% ; n=34$ ).

\section{Results and discussion}

\section{Modifications to the QuPPe-Method}

As mentioned in the section Materials and Methods, modifications were made to the QuPPe-Method because process efficiencies and matrix interferences varied considerably and unsystematically between various soya bean meal samples when using the standard method protocol. A similar observation was also made for the analysis of paraquat and diquat in cowpea samples (Pizzutti et al., 2016). First of all, water has not been added to the sample homogenate $(10 \mathrm{~mL}$ of water is typically given to $5 \mathrm{~g}$ of sample) because, for some tested soya bean meals, the extraction efficiencies turned out to be up to $55 \%$ lower when water was added. This finding may be in contrast to the assumption, that the addition of water assists the wetting process of dry samples to make pesticides better available for the extraction (Pizzutti et al., 2012). Moreover, it turned out that the soaking time of the water also seems to be not negligible because the process efficiency (defined according to Buhrman et al., 1996 - includes extraction efficiency and matrix interferences) was shown to be up to $30 \%$ lower when soaking time was 60 min instead of no soaking time, concluding that (1) extraction efficiencies were lower, (2) matrix interferences were higher or (3) a combination of both occurred. Following the standard method protocol for extraction $(10 \mathrm{~mL}$ of $1 \%$ formic acid in methanol as extraction solution; 15 min extraction at $80{ }^{\circ} \mathrm{C}$ ), process efficiencies were not satisfying and even around $0 \%$ for some test materials. Low recoveries using the standard method protocol were also shown for the analysis of paraquat in other matrices like wheat and chia seeds (Bauer et al., 2018). Optimal extraction conditions were evaluated using various extraction parameters (Table 2).

Table 2 Parameters tested for the extraction of paraquat from soya bean meal. Parameters that were finally used for the extraction of the samples are indicated in bold

\begin{tabular}{|c|c|}
\hline Parameter & Variation \\
\hline Particle size & $1 \mathrm{~mm} ; \mathbf{0 . 5} \mathbf{~ m m}$ \\
\hline Water addition & Yes $(10 \mathrm{~mL}) ;$ None \\
\hline Soaking time of water & 0 min; 15 min; 30 min; 45 min; 60 min \\
\hline Extraction apparatus & Horizontal shaker; orbital shaker; ultrasonic bath \\
\hline \multirow[t]{9}{*}{ Extraction solvent } & $1 \%$ formic acid in $\mathrm{MeOH}$ \\
\hline & $5 \%$ formic acid in $\mathrm{MeOH}$ \\
\hline & $5 \%$ formic acid in $\mathrm{MeOH} / \mathrm{H}_{2} \mathrm{O}(45 / 50, \mathrm{v} / \mathrm{v})$ \\
\hline & $\mathrm{MeOH} / 0.1 \mathrm{M} \mathrm{HCl}(50 / 50, \mathrm{v} / \mathrm{v})$ \\
\hline & $\mathrm{MeOH} / 0.5 \mathrm{M} \mathrm{HCl}(50 / 50, \mathrm{v} / \mathrm{v})$ \\
\hline & $\mathrm{MeOH} / 0.1 \mathrm{M} \mathrm{HCl}(60 / 40, v / v)$ \\
\hline & $\mathrm{MeOH} / 0.5 \mathrm{M} \mathrm{HCl}(60 / 40, \mathrm{v} / \mathrm{v})$ \\
\hline & $\mathrm{MeOH} / 0.75 \mathrm{M} \mathrm{HCl}(60 / 40, \mathrm{v} / \mathrm{v})$ \\
\hline & $\mathrm{MeOH} / 1 \mathrm{M} \mathrm{HCl}(60 / 40, \mathrm{v} / \mathrm{v})$ \\
\hline Extraction volume & $10 \mathrm{~mL} ; \mathbf{2 5} \mathbf{~ m L}$ \\
\hline Extraction temperature & Room temperature; $80^{\circ} \mathrm{C}$ \\
\hline Extraction time & 15 min; 30 min; 60 min; 90 min; 120 min \\
\hline Soaking time of extraction solvent & None; 15 min; 30 min; 45 min; 60 min \\
\hline Dilution of extract solution & Undiluted; 1:10; 1:5; 1:2 \\
\hline Clean-up & Solid phase extraction using Strata ${ }^{\oplus}$ WCX; Oasis ${ }^{\circledast}$ HLB; None \\
\hline
\end{tabular}


There was a slight trend that samples from Argentina and India yielded worse process efficiencies than those from Brazil. Variations in process efficiencies could be attributed to different protein and carbohydrate contents and compositions or different varieties of soya beans and were not investigated in detail.

In addition to the extraction procedure, the chromatographic analysis was also optimized. Paraquat has, in general, a limited retention and poor peak shape on reversed phase columns, which are commonly used in multi-analyte LC-MS/MS analysis, because of its low hydrophobicity and basic properties. The QuPPemethod provides an alternative approach using the Obelisc $\mathrm{R}^{\text {mi }}$ column (SIELC Technologies) to achieve an optimum retention and peak shape for paraquat. The Obelisc R column consists of a traditional long hydrophobic chain and negatively charged groups so that Paraquat can be retained by a cation-exchange mechanism (SIELC Technologies, 2015). However, bad chromatograms were partly yielded with the Obelisc $R$ column depending on the sample material (Fig. 1). Most probably, matrix components could not be separated accurately and, thus, interfered with the analyte and suppressed the analyte signal. In conclusion, it was not possible to use the Obelisc R column for the analysis of paraquat in soya bean meal samples. As paraquat is very polar and ionic, another approach for its analysis is hydrophilic interaction liquid chromatography (HILIC) (Hao et al., 2013). With HILIC, paraquat was analyzed in the past in, for example, human urine, cabbage, lake water, palm oil, cereals, and fruits (Whitehead et al., 2010; Robb and Eitzer, 2011; Zou et al., 2014; Francesquett et al., 2019; Halim et al., 2019; Oulkar et al., 2019). For the analysis of paraquat in soya products, there is, to the best of my knowledge, no single residue method published elsewhere. However, based on information and experiences given in the literature, a zwitterionic stationary phase (SeQuant ZIC - HILIC, Merck) was tested and showed a good retention, electrospray ionization efficiency, and reproducibility (Fig. 1).

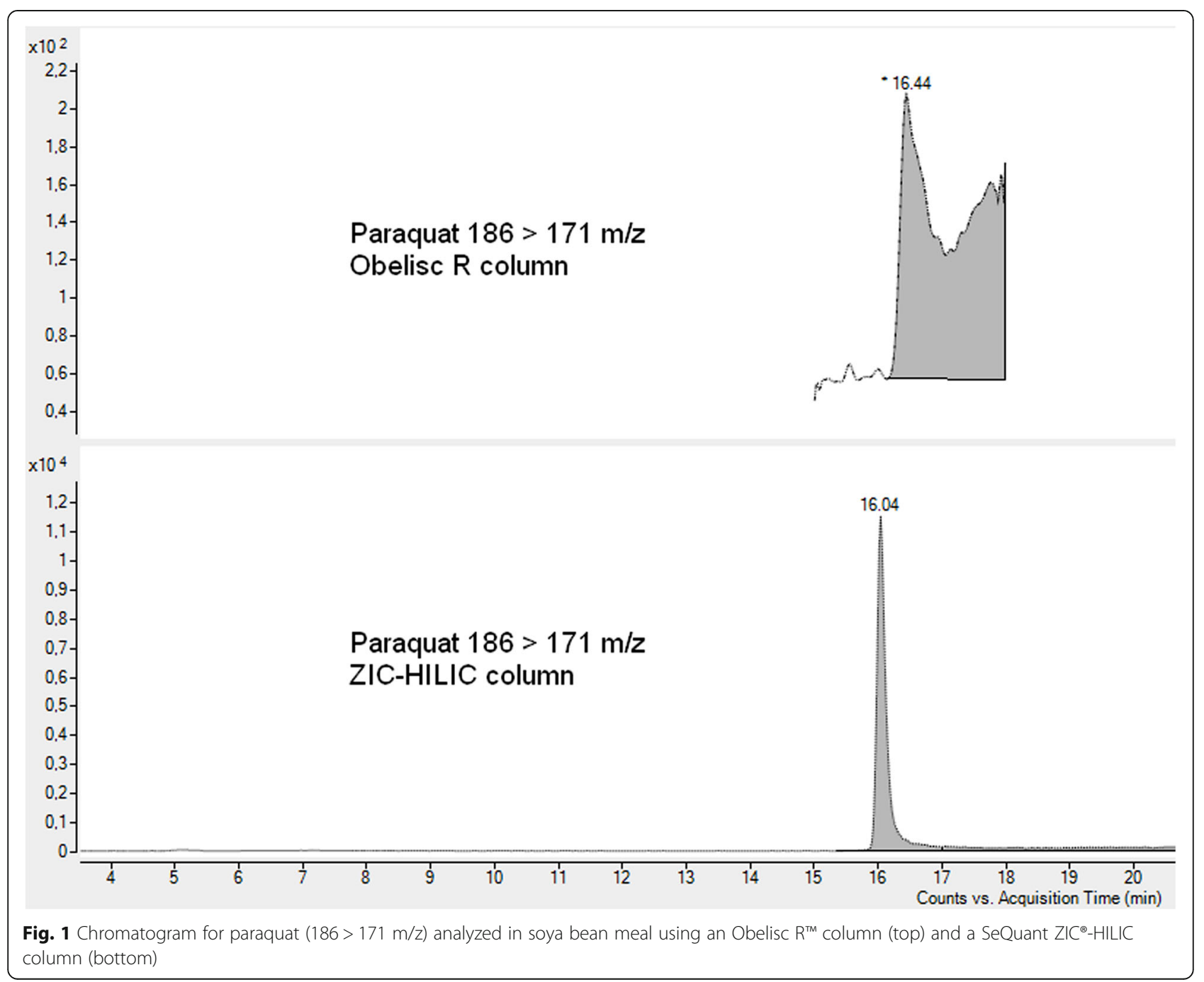


Consequently, all samples were analyzed using the SeQuant ZIC ${ }^{\oplus}$-HILIC column.

\section{Monitoring results}

Figure 2 presents an overview of the findings of paraquat residues, highlighting the significant differences between the various regions of origin and soya products and between GMO and Non-GMO material. Paraquat was detected in $66 \%$ of the samples above the LOQ of $0.008 \mathrm{mg} / \mathrm{kg}$. The majority of the samples that contained residues came from Brazil with $69 \%$, followed by Argentina with $4 \%$, and the USA and Russia with $3 \%$, respectively. In Brazil, Argentina, and the USA, more than $94 \%$ of the cultivation area is cultivated with genetically modified soya (Ovid, 2018). Given this situation, it is hardly surprising that paraquat residues were almost entirely found in samples from those countries because it is well-known that paraquat-based formulations can still be effectively used when, for example, glyphosateresistant weeds have developed (Syngenta Crop Protection AG, 2019). A considerable proportion of $18 \%$ of the found paraquat residues could not be assigned to a region of origin so that these data is, unfortunately, rather difficult to interpret. The samples from Austria, Canada, India, Lithuania, PR China, and Ukraine were below the LOQ of $0.008 \mathrm{mg} / \mathrm{kg}$. Those samples were mainly declared as Non-GMO material (except the sample from Canada) and, moreover, the use of paraquat has not been authorized in at least Austria and Lithuania as being members of the EU. Furthermore, $60 \%$ of the samples with paraquat residues were cultivated using genetically modified soybeans, whereas $32 \%$ where cultivated using Non-GMO material. These results agree with the findings of the different regions of origin. Also, the Non-GMO material containing paraquat residues came mainly from Brazil (76\%), followed by Russia $(11 \%)$, and Norway (3\%). Figure 2 also reveals that of the different soya products, $88 \%$ of paraquat residues were found in soya bean meal and $9 \%$ in soya bean protein concentrate. Soya beans and soya bean hulls had the lowest proportion of paraquat residues at $2 \%$, respectively, followed by soya bean expeller with $0 \%$.

In general, the concentrations ranged from 0.008 to $0.070 \mathrm{mg} / \mathrm{kg}$. As shown in Fig. 3, the concentrations for

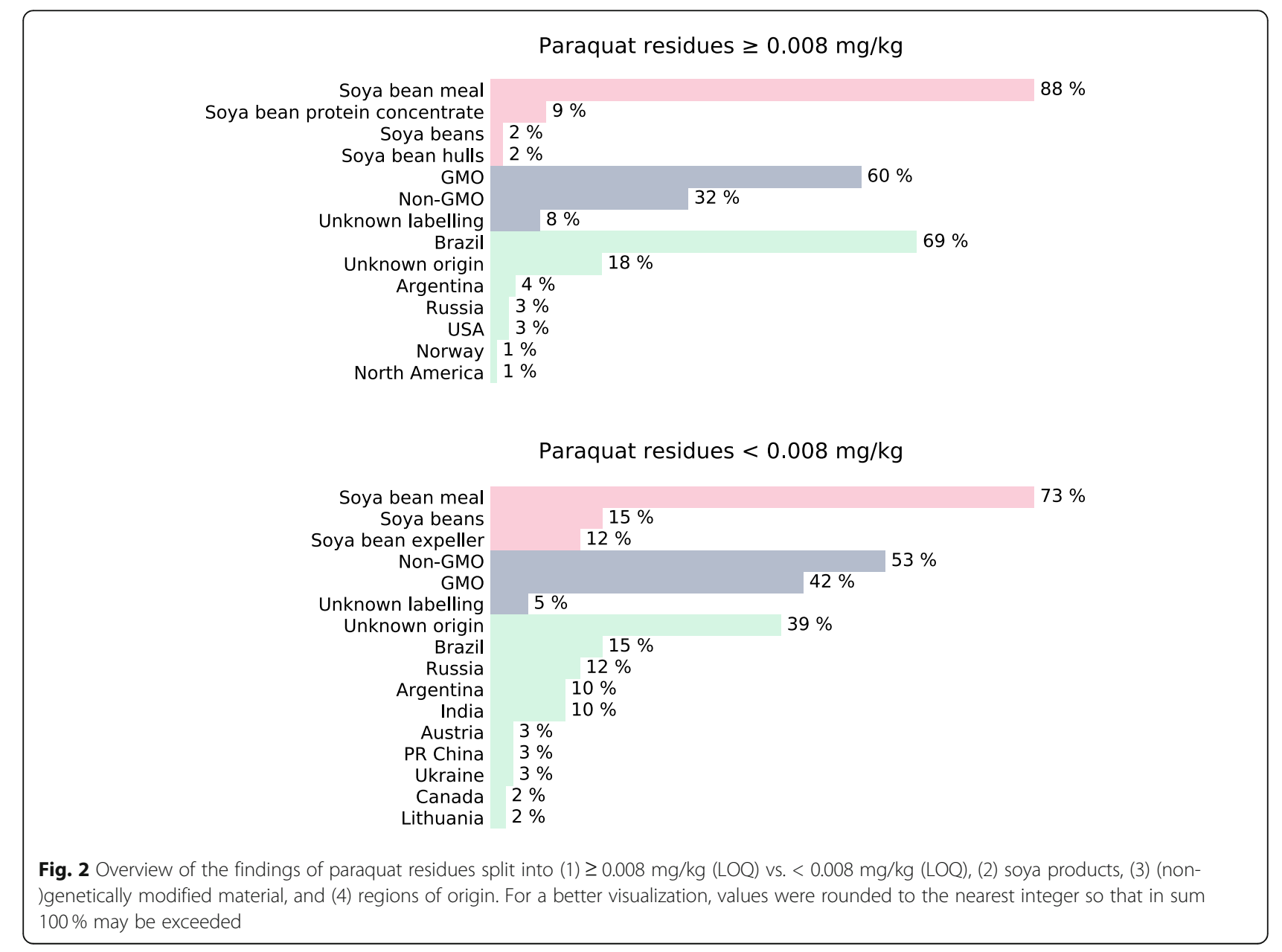


most of the samples were below $0.04 \mathrm{mg} / \mathrm{kg}$. Only $7 \%$ of the quantified samples were above $0.04 \mathrm{mg} / \mathrm{kg}$ and, thus, above the European maximum residue level for soya beans (cf. section Conclusions). The highest paraquat concentration of $0.070 \mathrm{mg} / \mathrm{kg}$ was found in one sample GMO-soya bean meal from Brazil. In general, the samples with concentrations above $0.04 \mathrm{mg} / \mathrm{kg}$ were mainly soya bean meals that were cultivated (1) in Brazil or the USA and (2) using genetically modified soya. A higher concentration of $0.06 \mathrm{mg} / \mathrm{kg}$ was also registered for one sample of soya bean hulls.

\section{Conclusions}

For all agricultural products for food and animal feed, pesticide maximum residue levels are set by the European Commission and, thus, harmonized throughout the EU via the Regulation (EC) No 396/2005 (European Commission, 2005). A maximum residue level (MRL) is the highest level of a pesticide residue that is legally tolerated in or on food or feed. According to Article 19 of Regulation (EC) No 396/2005, agricultural products that exceed MRLs must not be processed and/or mixed for dilution purposes with a view to placing them on the market as food or feed or feeding them to animals. MRLs apply to fresh products, but also to processed products, considering that the processing may cause a dilution or concentration of the pesticide. When assessing whether a sample contains a residue which exceeds the MRL, a default expanded measurement uncertainty of $\pm 50 \%$ has to be applied. For soya beans, an MRL of
$0.02 \mathrm{mg} / \mathrm{kg}$ is set, which means that results above $0.04 \mathrm{mg} / \mathrm{kg}$ are not compliant with the MRL. For processed soya products like soya bean meal, the enforcement of the MRL is limited. Therefore, so-called processing factors must be considered when checking for compliance. For some pesticide-matrix combinations, processing factors are available via databases, for example via the European database of processing factors for pesticides in food (Scholz et al., 2018). Those processing factors are not legally binding. Nevertheless, they are a useful tool for the assessment of pesticide residues in food and feed. For paraquat in soya products, reliable processing factors are not available, which complicates considerably the enforcement of the MRL according to Regulation (EC) No 396/2005. Our results clearly show that paraquat residues in soya products might exceed the MRL for soya beans of $0.02 \mathrm{mg} / \mathrm{kg}$ or $0.04 \mathrm{mg} / \mathrm{kg}$ taking into account the default expanded measurement uncertainty. Around $5 \%$ of our samples were not compliant with the MRL and, thus, required national enforcement actions. However,

The lack of processing factors, especially for soya bean meal as the most important soya product in the feed industry, is problematic and complicates the legal enforcement of the MRL. For the future, it is desirable to establish (1) reliable processing factors for paraquat in soya products or (2) MRLs for processed products to strenghten the national authorities in the EU in controlling and enforcing the Regulation (EC) No 396/2005.

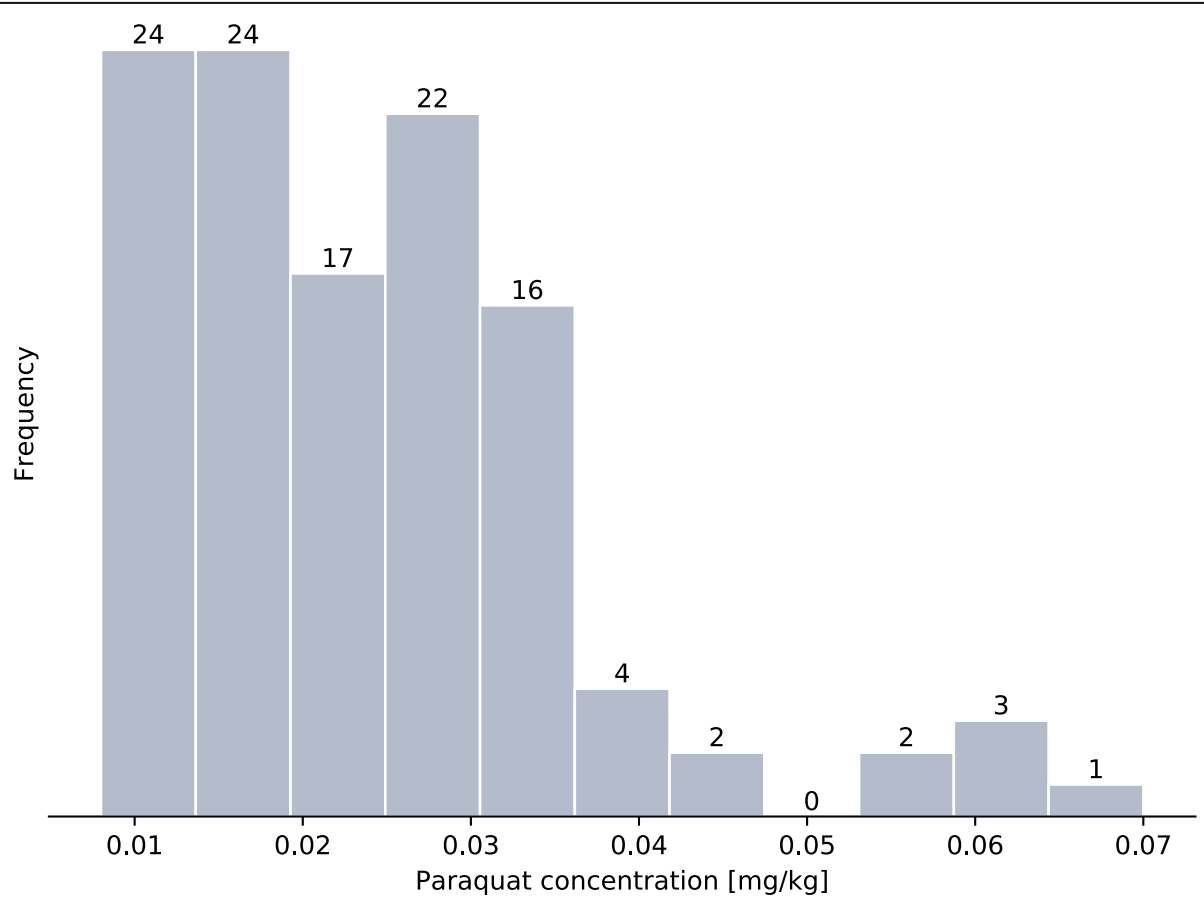

Fig. 3 Frequency of the paraquat concentrations [mg/ $/ \mathrm{kg}$ ] observed above the limit of quantification of $0.008 \mathrm{mg} / \mathrm{kg}$ 


\section{Abbreviations}

EU: European Union; GMO: Genetically modified organism; HILIC: Hydrophilic interaction liquid chromatography; LOQ: Limit of quantification; MRL: Maximum residue level; MRM: Multiple reaction monitoring; PEEK: Polyether ether ketone; QuPPe: Quick Polar Pesticides Method; ZICHILIC: Zwitterionic hydrophilic interaction liquid chromatography

\section{Acknowledgements}

The author thanks Birte Ristau and Theis Oellrich for their assistance in the laboratory, Jens Künnemeyer for useful discussions and proofreading, Daniel Heydebreck for helping to create the figures, and the Working Group for Organic Analysis of the Association of German Agricultural Analytic and Research Institutes (VDLUFA) for scientific exchange and participation in the ring trial.

\section{Authors' contributions}

The author(s) read and approved the final manuscript.

\section{Funding}

As part of the Lower Saxony State Office for Consumer Protection and Food Safety, the Feed Institute is funded by using public money.

\section{Availability of data and materials}

The dataset supporting the conclusions of this article is available in the Zenodo repository via https://doi.org/10.5281/zenodo.3828295.

\section{Declarations}

\section{Competing interests}

The authors declare no competing financial interest.

Received: 31 March 2021 Accepted: 26 July 2021

Published online: 12 September 2021

\section{References}

Anastassiades M, Kolberg DI, Benkenstein A et al (2016) Quick Method for the Analysis of numerous Highly Polar Pesticides in Foods of Plant Origin via LCMS/MS involving Simultaneous Extraction with Methanol (QuPPe-Method). EU Reference Laboratory for Single Residue Method (EURL-SRM), Stuttgart, Germany, Version 9.2

Babatunde MM, Oladimeji AA, Balogun JK (2001) Acute Toxicity of Gramoxone to Oreochromis niloticus (Trewavas) in Nigeria. Water Air Soil Pollut 131(1):1-10. doi:https://doi.org/10.1023/A:1011959514500

Bauer A, Luetjohann J, Rohn S et al (2018) Development of an LC-MS/MS Method for Simultaneous Determination of the Quaternary Ammonium Herbicides Paraquat, Diquat, Chlormequat, and Mepiquat in Plant-Derived Commodities. Food Anal Methods 11(8):2237-2243. doi:https://doi.org/10.1 007/s12161-018-1201-6

Boudreaux JM, Griffin JL (2011) Application Timing of Harvest Aid Herbicides Affects Soybean Harvest and Yield. Weed Technol 25(1):38-43. doi:https://doi org/10.1614/WT-D-10-00045.1

Buhrman DL, Price PI, Rudewicz PJ (1996) Quantitation of SR 27417 in human plasma using electrospray liquid chromatography-tandem mass spectrometry: A study of ion suppression. J Am Soc Mass Spectrom 7(11): 1099-1105. doi:https://doi.org/10.1016/S1044-0305(96)00072-4

Costello S, Cockburn M, Bronstein J et al (2009) Parkinson's Disease and Residential Exposure to Maneb and Paraquat From Agricultural Applications in the Central Valley of California. Am J Epidemiol 169(8):919-926. doi:https:// doi.org/10.1093/aje/kwp006

Dinis-Oliveira RJ, Remião F, Carmo $\mathrm{H}$ et al (2006) Paraquat exposure as an etiological factor of Parkinson's disease. Neurotoxicology 27(6):1110-1122. doi:https://doi.org/10.1016/j.neuro.2006.05.012

EuG (2007) Jugdment of 11 July 2007, Kingdom of Sweden/Commission of the European Communities, T-229/04, EU:T:2007:217

European Commission (2015) Analytical quality control and method validation procedures for pesticide residues analysis in food and feed (SANTE/11945/ 2015)

European Commission (2017a) Commission Regulation (EU) 2017/1017 of 15 June 2017 amending Regulation (EU) No 68/2013 on the Catalogue of feed materials
European Commission (2017b) Analytical quality control and method validation procedures for pesticide residues analysis in food and feed (SANTE/11813/ 2017)

European Commission (2005) Regulation (EC) No 396/2005 of the European Parliament and of the Council of 23 February 2005 on maximum residue levels of pesticides in or on food and feed of plant and animal origin and amending Council Directive 91/414/EEC

Francesquett JZ, Rizzetti TM, Cadaval TRS et al (2019) Simultaneous determination of the quaternary ammonium pesticides paraquat, diquat, chlormequat, and mepiquat in barley and wheat using a modified quick polar pesticides method, diluted standard addition calibration and hydrophilic interaction liquid chrom. J Chromatogr A 1592:101-111. doi:https://doi.org/10.1016/j. chroma.2018.12.060

Garcia-Febrero R, Salvador J-P, Sanchez-Baeza F, Marco M-P (2014) Rapid method based on immunoassay for determination of paraquat residues in wheat, barley and potato. Food Control 41:193-201. doi:https://doi.org/10.1016/j. foodcont.2014.01.008

Halim N, Kuntom A, Shinde R, Banerjee K (2019) Determination of Paraquat Residues in Palm Oil by High-Performance Liquid Chromatography with UV and Tandem Mass Spectrometry. Eur J Lipid Sci Technol 121(8):1900092. doi: https://doi.org/10.1002/ejlt.201900092

Hao C, Zhao X, Morse D et al (2013) Optimized liquid chromatography tandem mass spectrometry approach for the determination of diquat and paraquat herbicides. J Chromatogr A 1304:169-176. doi:https://doi.org/10.1016/j. chroma.2013.07.033

Hoppin JA, Umbach DM, London SJ et al (2002) Chemical Predictors of Wheeze among Farmer Pesticide Applicators in the Agricultural Health Study. Am J Respir Crit Care Med 165(5):683-689. doi:https://doi.org/10.1164/ajrccm.165. 5.2106074

Kawase S, Kanno S, Ukai S (1984) Determination of the herbicides paraquat and diquat in blood and urine by gas chromatography. J Chromatogr A 283:231240. doi:https://doi.org/10.1016/S0021-9673(00)96258-7

Leboulanger C, Bouvy M, Pagano M et al (2009) Responses of Planktonic Microorganisms from Tropical Reservoirs to Paraquat and Deltamethrin Exposure. Arch Environ Contam Toxicol 56(1):39-51. doi:https://doi.org/10.1 007/s00244-008-9164-z

Mallat E, Barzen C, Abuknesha R et al (2001) Fast determination of paraquat residues in water by an optical immunosensor and validation using capillary electrophoresis-ultraviolet detection. Anal Chim Acta 427(2):165-171. doi: https://doi.org/10.1016/S0003-2670(00)01016-3

Muangphra P, Kwankua W, Gooneratne R (2014) Genotoxic effects of glyphosate or paraquat on earthworm coelomocytes. Environ Toxicol 29(6):612-620. doi: https://doi.org/10.1002/tox.21787

National Center for Biotechnology Information (2020) PubChem Database. Paraquat, CID = 15939. https://pubchem.ncbi.n/m.nih.gov/compound/Para quat. Accessed 4 May 2020

Oulkar D, Shinde R, Khan Z, Banerjee K (2019) High throughput residue analysis of paraquat and diquat involving hydrophilic interaction liquid chromatographic separation and mass spectrometric determination. Food Addit Contam Part A 36(1):120-130. doi:https://doi.org/10.1080/19440049.201 8.1547424

Ovid (2018) Verband der ölsaatenverarbeitenden Industrie in Deutschland e. V. https://www.ovid-verband.de/positionen-und-fakten/ovid-diagramme/. Accessed 30 Apr 2020

Perry ED, Ciliberto F, Hennessy DA, Moschini G (2016) Genetically engineered crops and pesticide use in U.S. maize and soybeans. Sci Adv 2 (8). doi:https:// doi.org/10.1126/sciadv. 1600850

Pizzutti IR, Kok A de, Cardoso CD et al (2012) A multi-residue method for pesticides analysis in green coffee beans using gas chromatographynegative chemical ionization mass spectrometry in selective ion monitoring mode. J Chromatogr A 1251:16-26. doi:https://doi.org/10.1016/j.chroma.2012. 06.041

Pizzutti IR, Vela GME, de Kok A et al (2016) Determination of paraquat and diquat: LC-MS method optimization and validation. Food Chem 209:248-255. doi: https://doi.org/10.1016/j.foodchem.2016.04.069

Powles SB (2008) Evolved glyphosate-resistant weeds around the world: lessons to be learnt. Pest Manag Sci 64:360-365. doi:https://doi.org/10.1002/ps.1525

Robb CS, Eitzer BD (2011) The Direct Analysis of Diquat and Paraquat in Lake Water Samples by per Aqueous Liquid Chromatography. LCGC North Am 29(1):54-59 
Schenker MB, Stoecklin M, Lee K et al (2004) Pulmonary Function and Exerciseassociated Changes with Chronic Low-Level Paraquat Exposure. Am J Respir Crit Care Med 170(7):773-779. doi:https://doi.org/10.1164/rccm.200403-2660C

Scholz R, van Donkersgoed G, Herrmann M et al (2018) Database of processing techniques and processing factors compatible with the EFSA food classification and description system FoodEx 2 Objective 3: European database of processing factors for pesticides in food. EFSA Support Publ 15(11):1510E. doi:https://doi.org/10.2903/sp.efsa.2018.EN-1510

Shivhare P, Gupta VK (1991) Spectrophotometric method for the determination of paraquat in water, grain and plant materials. Analyst 116(4):391-393. doi: https://doi.org/10.1039/AN9911600391

SIELC Technologies (2015) Obelisc ${ }^{\text {TM }}$ HPLC Columns - Liquid Separation Cell Technology. https://www.sielc.com/wp-content/uploads/2015/11/SIELC_ Obelisc_Intro.pdf. Accessed 14 Apr 2020

Souza D, De, Machado SAS, Pires RC (2006) Multiple square wave voltammetry for analytical determination of paraquat in natural water, food, and beverages using microelectrodes. Talanta 69(5):1200-1207. doi:https://doi. org/10.1016/j.talanta.2005.12.045

Syngenta Crop Protection AG (2019) Paraquat information center. http://www.pa raquat.com/en. Accessed 7 May 2020

Tanner CM, Kamel F, Ross GW et al (2011) Rotenone, Paraquat, and Parkinson's Disease. Environ Health Perspect 119(6):866-872. doi:https://doi.org/10.1289/ ehp.1002839

Wesseling C, Van Wendel De Joode B, Ruepert C et al (2001) Paraquat in developing countries. Int J Occup Environ Health 7(4):275-286. doi:https:// doi.org/10.1179/oeh.2001.7.4.275

Whitehead RD, Montesano MA, Jayatilaka NK et al (2010) Method for measurement of the quaternary amine compounds paraquat and diquat in human urine using high-performance liquid chromatography-tandem mass spectrometry. J Chromatogr B 878(27):2548-2553. doi:https://doi.org/10.1016/ j.jchromb.2009.09.029

Zou T, He P, Cao J, Li Z (2014) Determination of paraquat in vegetables using HPLC-MS-MS. J Chromatogr Sci 53(2):204-209. doi:https://doi.org/10.1093/ chromsci/bmu041

\section{Publisher's Note}

Springer Nature remains neutral with regard to jurisdictional claims in published maps and institutional affiliations.

Ready to submit your research? Choose BMC and benefit from:

- fast, convenient online submission

- thorough peer review by experienced researchers in your field

- rapid publication on acceptance

- support for research data, including large and complex data types

- gold Open Access which fosters wider collaboration and increased citations

- maximum visibility for your research: over $100 \mathrm{M}$ website views per year

At $\mathrm{BMC}$, research is always in progress.

Learn more biomedcentral.com/submissions 